\title{
Diplomasi Ekonomi dan Militer India di Asia Tenggara sebagai Pendukung Keberadaan Kluster Industri Militer
}

\author{
Ismiyatun \\ Prodi Hubungan Internasional, Universitas Wahid Hasyim Semarang \\ E-mail: ismiyatun@unwahas.ac.id
}

\begin{abstract}
Abstrak
Tulisan ini mengeksplorasi Asia Tenggara sebagai pasar yang potensial untuk Kluster Industri Militer. Tiga Negara yang merepresentasikan area ini adalah Myanmar, Thailand, dan Singapura. Setiap Negara memiliki spesifikasi yang unik, termasuk keuntungan absolut yaitu Negara India sebagai Negara tetangga. Myanmar memiliki potensi geopolitik dan sumber daya alam mentah yang berlimpah, sedangkan Singapura memiliki keuntungan kompetitif yaitu dapat mengelola sektor jasa. Dibandingkan dengan dua Negara sebelumnya, Thailand hanya memiliki keuntungan dari diaspora India sebagai komponen pendukung dari keberlanjutan dari Kluster Industri Militer. Tapi, kuantitas ini memberikan jaminan bahwa India tidak pernah mengabaikan posisi Negara di setiap kebijakannya. Selain itu, penulis menyimpulkan jika ekonomi dan diplomasi militer harus diambil oleh Least Developed Country, khususnya sebagai ekonomi, yang menempatkan industry militer sebagai prioritas pengembangan sub-sektor. Argumentasi yang paling mendesak adalah model monopsoni yang memiliki latar belakang kostumer yang minimum, sedangkan ketersediaan volume permintaan absolut untuk kinerja kluster.
\end{abstract}

Kata Kunci: diplomasi ekonomi dan militer, potensi pasar, kluster industri militer

\begin{abstract}
This paper explored of South East Asia as potential market for India Military Industrial Cluster. Three states, representated this area are Myanmar, Thailand, and Singapore. Each of states had unique specification which included on their absolute advantage for India as neighbour state. Myanmar had geopolitics potential and wealth raw material, while Singapura owned competitive advantage that generally could manage service sector. Being compared with two states before, Thailand just had advantage of Indian diaspora as proponent component of military industrial cluster sustainability. But this quantity gave guarantee so India never ignored position of the state in every step of its policy. Beside that, we concluded if economic and military diplomacy must be taken by Least Developed Country, especially as economic actor, which put military industry as sub sector development priority. Argument for the urgent was monopsony style had background minimum costumer, while demand volume availability as absolute for performance of cluster.
\end{abstract}

Keywords : economic and military diplomacy, potential market, military industrial cluster

\section{Pendahuluan}

Sejak awal kemerdekaannya di tahun 1947, industri militer India mendapatkan perhatian utama dari segenap pembuat kebijakan negara. Dorongan politis bagi industri ini adalah konflik yang berkepanjangan dengan Pakistan, Srilanka dan Tiongkok sebagai negara tetangga. Konflik ini semakin melebar sampai ke persoalan demokratisasi Burma (Myanmar). Tujuan utama India dalam pengembangan industri ini adalah untuk memenuhi kebutuhan persenjataan modern bagi angkatan bersenjatanya. Target utamanya adalah terciptanya suatu tingkat kemandirian militer yang mampu memberikan dampak penangkalan atas ancaman maupun tekanan dari negara lain.

Di awal tahun 1960an - masa Perang Dingin, India berusaha mengembangkan industri militernya dengan lebih mengandalkan impor maupun bantuan 
persenjataan dari Uni Soviet dan beberapa negara Barat, tingkat impor militer India tetap tinggi dari tahun ke tahun. India kemudian, mengembangkan sistem offset, khususnya dengan Rusia, Perancis dan Inggris. Tujuannya adalah untuk memenuhi kebutuhan militer domestik, mengurangi ketergantungan terhadap impor / bantuan militer dari negara lain, dan mencapai tingkat kemandirian militer yang lebih baik melalui transfer teknologi.

Selain offset, India juga mengembangkan senjata lapis baja, roket pembawa bom tandan, satelit, radar dan rudal balistik dengan tenaga nuklir. Khusus program yang terakhir tersebut, dicanangkan IGMDP (Indigenous Guided Missile Development Programme), suatu program nasional pengembangan rudal bertenaga nuklir, yang melibatkan firma swasta, Universitas riset bahkan MNC (Perusahaan Multi Nasional) India seperti Tata Group. Beberapa pusat riset militer didirikan dalam kluster teknologi yang terletak di Bangalore, Hyderabad dan sekitarnya untuk kepentingan produksi dan inovasi berbagai senjata berteknologi tinggi tersebut. Dari program tersebut, berhasil dikembangkan lima jenis rudal, antara lain Agni ( rudal balistik regional jarak menengah), Pritvi ( rudal balistik jarak pendek), Akash dan Trishul (rudal SAM/Surface to Air Missile, jarak menengah), dan Nag (ATGM /Anti Tank Guided Missile, rudal anti tank). ${ }^{1}$

\footnotetext{
${ }^{1}$ Hoyt, Timothy d. 2006, Military industry and regional defense policy: India, Iraq, and Israel, London: Routledge.
}

Neuman ${ }^{2}$, Andrew L Ross ${ }^{3}$ dan Bitzinger $^{4}$ menghubungkan tingkat keberhasilan usaha negara berkembang dalam pengembangan kluster teknologi ini dengan konsep RMA (Revolution in Military Affairs), semua menyepakati arti pentingnya kluster teknologi guna mengantisipasi tantangan industri militer di abad 21. Neumann berpendapat bahwa RMA mampu memberikan peluang komersialisasi industri militernya melalui ekspor jasa militer sebagai suatu produk pelengkap. Kedua peneliti lainnya mendukung pendapat ini dengan dalih RMA menuntut keberadaan NCW (Network Centric Warfare) atau jaringan tunggal yang menghubungkan orang, platform, senjata, sensor, dan berbagai keputusan tentang bantuan militer dari negara lain. Kemampuan akses yang dimiliki kluster akan mampu memfasilitasinya.

Tiga konsep yang menonjol di negara berkembang ketika memutuskan untuk mengembangkan kluster industri militer adalah keberadaan teknokrat, state owned enterprises serta andil modal asing, baik dalam bentuk investasi langsung (FDI) maupun investasi portofolio. Kaum teknokrat berpengaruh di dalam kelangsungan serta pengembangan

\footnotetext{
${ }^{2}$ Neuman, Stephanie G. 1994. “Arm Transfers, Military Assistance, and Defense Industries : Socio economic Burden or Opportunity ?". Annal of the American Academy of Political and Social Science Vol 535 : The Arm Trade : Problem and Prospect in the Post Cold War World (Sept)

${ }^{3}$ Ross, Andrew L. Peter Dombrowski. 2008.'The Revolution in Military Affairs, Transformation and the Defence Industry". Security Challenges, Vol. 4, No. 4 (Summer)

${ }^{4}$ Bitzinger, Richard A. 2009. The Modern Defense Industry : Political, Economy, Technological Issues. California : ABC-CLIO
} 
modal sosial sehingga bersama-sama dengan pembuat kebijakan lainnya memutuskan strategi industri yang digunakan apakah ISI, EOI atau gabungan diantara keduanya. Selain itu juga sebagai segmen eksekutif, kaum teknokrat aktif mengembangkan diplomasi ekonomi dengan negara industri maju maupun negara berkembang, untuk mendukung terbentuknya jaringan kluster industri militer internasional. Melalui jaringan ini negara berkembang mampu mempengaruhi pasar tenaga kerja skill internasional.

Bersama-sama dengan SoE, golongan ini merupakan wujud dari keberadaan suatu embedded autonomy, sebagai salah satu ciri khas yang menonjol di dalam developmentalist state theory. Secara teoritis, pengendalian modal asing di dalam suatu perusahaan hanya mampu dilakukan apabila jumlahnya maksimal $50 \%$. Melalui penelitian ini, akan ditelaah lebih lanjut kemampuan dari teori tersebut dalam menjelaskan tingkat keterlibatan pemerintah India dalam internalisasi industri militer melalui kluster teknologi.

Developmentalist state theory
memiliki landasan dasar dilakukannya
diplomasi ekonomi atas suatu kluster
berteknologi tinggi. Bahkan apabila berhasil
akan meningkat menjadi diplomasi militer
dimana suatu negara menawarkan SoE (State
owned Enterprises) ataupun lembaga yang
dimilikinya guna menjalankan fungsi sebagai
konsultan, pelatih, penyedia maupun
pendukung dalam urusan militer. Selain
eksistensi suatu kluster industri militer

merupakan hasil dari diplomasi ekonomi. Kluster ini juga mampu dijadikan suatu instrumen diplomasi ekonomi untuk memberdayakan berbagai sumber daya alam maupun manusia melalui suatu bisnis yang berkaitan dengan pembangkit energi listrik bertenaga nuklir seperti kasus Korea Selatan juga pemasaran berbagai produk kluster ini guna kepentingan sipil.

Di sisi lain, diplomasi militer yang dijalankan oleh negara berkembang melalui kluster ini selain memasarkan suatu jasa militer seperti tersebut di atas juga bisa dilakukan melalui kerjasama riset militer dengan negara berkembang lainnya maupun industri maju. Bagi developmentalist state, diplomasi militer yang dijalankan atas negara lain, integral dengan kebijakan nasional dalam persenjataan sehingga diplomasi militer memberikan peluang bagi mereka untuk memperoleh pengakuan dari negara lain atas kekuatan militer mereka sekaligus kesempatan untuk alih teknologi dan pengembangan modal manusia.

Joseph S Nye Jr, ilmuwan yang pernah menjabat sebagai Assistant Secretary of Defense for International Security Affairs pada masa pemerintahan Bill Clinton (Partai Demokrat), tergolong kelompok dengan perhatian khusus pada pengembangan kluster industri militer sebagai instrumen diplomasi, khususnya perberdayaannya menjadi smart power. ${ }^{5}$ Karena kekuatan khusus yang dibutuhkan dalam implikasi RMA selain

\footnotetext{
${ }^{5}$ Nye, Joseph Samuel. Jr. 2004. Soft Power : the Means to Success in World Politics. New York : Public Affairs
} 
diplomasi, maka muncul berbagai kritikan dari para akademisi atas konsep ini. Biegon ${ }^{6}$ menilai konsep Nye masih terlalu dangkal karena masih bersifat narasi persuasif belum diwujudkan ke dalam suatu konsep strategis. Padahal negara berkembang sudah menjalankan diplomasi ekonomi maupun militer melalui kluster ini, meskipun masih dalam skala regional cyber yang dimilikinya, namun belum memiliki smart power, yang mampu menyatukan antara hard power dengan soft power. ${ }^{7}$ Dalam artikelnya ${ }^{8}$, Nye mendefinisikan cyber power sebagai suatu kemampuan untuk menggunakan cyber space untuk meraih berbagai keuntungan dan pengaruh sesuai dengan target dan keinginannya.

Di India, kedua jenis diplomasi ini dijalankan oleh pemerintah dan dan swasta (RUR/Raksha Udyog Ratna, SMSE /Small Medium Scale Enterprises) secara beriringan untuk menjaga kelangsungan industri militer. Diplomasi ekonomi dijalankan bagi peningkatan kemampuan kluster, sedangkan diplomasi militer mendukungnya melalui instrumen dialog, latihan bersama, partisipasi sebagai pasukan perdamaian $\mathrm{PBB}$ (peace keeping, peace building) sampai dengan perjanjian militer sehingga meningkatkan pemahaman terhadap integritas keamanan

\footnotetext{
${ }^{6}$ Biegon, Rubrick. 2013. "The Banality of Smart Power : Reconstituting US Hegemony after ush".International Paper that was submitted for University of Kent POLIR Post Grad Conference 17 May.

${ }^{7}$ Nye, Joseph Samuel. Jr. 2011. The Future of Power. New York. Public Affairs

${ }^{8}$ Nye, Joseph Samuel. Jr. 2010. Cyber Power. Belfer Center for Science \& International Affairs .May.
}

domestik baik secara bilateral maupun multilateral.

Artikel ini mengupas bagaimana pemberdayaan kluster teknologi tinggi di India melalui diplomasi ekonomi dan militer dengan target wilayah Asia Tenggara sebagai salah satu pasar potensial bagi industri militernya.

\section{Diplomasi Ekonomi India bagi Asia} Tenggara sebagai Pasar Potensial Industri Militer

Tujuan utama diplomasi ekonomi bagi negara berkembang adalah peningkatan arus masuk eksternal dalam neraca pembayaran, baik neraca berjalan maupun modal sehingga kuantitas FDI (Foreign Direct Investment) dan cadangan devisa mampu menjamin keseimbangannya terhadap arus keluar. Dalam sistem anggaran defisit, diplomasi ini menjadi sangat krusial karena investasi dan kredit dari luar negeri diletakkan pada pos pengeluaran. Konsekuensinya, melalui diplomasi ekonomi negara harus mampu meyakinkan para investor internasional melalui regulasi dan kuantitas sekuritas domestiknya.

Tahapan diplomasi ekonomi India secara umum, menurut Kishan S Rana ${ }^{9}$ terbagi menjadi empat fase, yakni:

a. Promosi Perdagangan (awal 1970an awal 1980an). Berawal dari kegoncangan harga minyak dunia di Timur Tengah pada tahun 1973, Pemerintah India menyadari potensi pasar wilayah kaya

\footnotetext{
${ }^{9}$ Rana, Kishan S \& Bipul Chatterjee. 2011. Economic Diplomacy : India's Experience. Rajasthan : CUTS International
} 
minyak ini cukup tinggi, bagi berbagai produksi barang maupun jasa. Sejumlah diplomat muda diterjunkan kesana dengan target peningkatan hubungan perdagangan. Status India sebagai eksportir tenaga dengan skill murah berawal dari fase ini.

b. Pembentukan Jaringan / Networking (awal 1980an - pertengahan 1980 an)

Merupakan tahap mobilisasi internal dan eksternal. Aktor non-Negara utama dalam fase ini adalah CII (Confederation of Indian Industry), FICCI (Federation of Indian Chambers of Commerce and Industry), Associated Chambers of Commerce and Industry of India (ASSOCHAM), Federation of Indian Export Organizations (FIEO). Mereka secara aktif bekerja sama dengan Kedutaan Besar India di berbagai negara guna mengejar pangsa pasar. Dominasi industri militer sebagai prioritas pembangunan, mulai terlihat nyata di setiap aspek kegiatan kerja sama yang diselenggarakan oleh berbagai instansi swasta di atas.

c. Promotion / Branding ( akhir 1980an akhir 1990an )

Masa pemeliharaan pangsa pasar melalui keterlibatan segenap aktor industri prioritas sebagai brand ambassador. Diplomasi swasta terlihat semakin mampu mendampingi diplomasi pemerintah melalui beragam forum promosi. India mulai dikenal sebagai salah satu OEM (Original Equipment Manufacture) maupun pelaksana BPO (Bussiness Process of Outsourcing) di samping menjadi pasar modal manusia yang cukup kompetitif dalam upah jika dibandingkan dengan negara berkembang lainnya.

d. Regulasi dan Pembetukan Rezim ( 2000 - ............)

Merupakan tahap pengelolaan secara struktural melalui jaringan organisasi internasional maupun regional. Posisi India dalam regulasi sangat lemah, hal ini sangat mempengaruhi perkembangan kluster industri militernya menuju tahap kematangan. Pangsa pasar global sulit diraih karena negara besar bersenjata nuklir (NWS / Nuclear Weapon State) menolak mengakui kompetensinya secara sejajar dengan mereka. Alternatifnya, India lebih berfokus pada jasa militer terkait dengan TI, maupun pesawat nir awak. Sementara legitimasinya sebagai NWS ditempuh melalui perundingan bilateral dengan setiap negara potensial.

Secara umum hubungan ekonomi India dengan Asia Tenggara, mengalami keragaman dengan fluktuasi cukup tinggi, intensitas hubungan ekonomi maupun politik Myanmar dan Thailand cukup tinggi, diantara mereka terikat kerja sama BCIM -EC maupun BIMSTEC dan beragam kerja sama bilateral seperti terurai di beberapa sub bagian di bawah ini. Meskipun demikian inisiasinya bagi kepentingan kluster industri militer India masih berada di tahap paling bawah. Mereka belum mampu diberdayakan secara potensial sebagai pasar industri militer. Karena dalam pembelian 
persenjataan, sebagian besar negara dalam kawasan ini masih menjadi konsumen utama AS, Rusia, Tiongkok dan Korea Selatan.

India berusaha mengatasi kendala dan hambatan peningkatan kontribusi kawasan ini melalui pola kerja sama ekonomi Free Trade Area, Double Taxation Agreement. Pembentukan kluster ekonomi dan perdagangan, kluster bantuan teknik dan pengembangan modal manusia. Melalui instrumen tersebut, ditargetkan secara tidak langsung kontribusi mereka terhadap pengembangan industri militer akan meningkat. Hal ini disebabkan karena sub sektor industri ini sangat tergantung pada persoalan tarif, pajak impor, alih teknologi dan dukungan modal manusia. Apabila India mulai meraih kepercayaan sebagai perantara Asia Tenggara dalam proses alih teknologi, maka tingkat kepercayaan meraka terhadap produksi militer India juga akan meningkat.

\section{Diplomasi Militer India di Asia Tenggara sebagai Pendukung Kluster Industri Militer}

Diplomasi militer dan kluster industri militer merupakan dua variabel yang terkait dan berhubungan sebab akibat. Melalui diplomasi militer yang dijalankan, suatu negara akan memperoleh dukungan eksternal dalam bentuk suatu kepatuhan, sampai dengan kelangsungan permintaan /penawaran bagi kelangsungan industri militernya. Sebaliknya kluster industri militer mampu menjadi deterrence / alat penangkal bagi segala serangan maupun ancaman dari domestik atau internasional.

Bentuk diplomasi militer cukup beragam, menyesuaikan kebutuhan masingmasing negara sebagai subyeknya. Muthanna menguraikan rincian obyek diplomasi militer seperti pada Tabel 1. Setiap jenis menunjukkan tingginya intensitas diplomasi militer India terhadap negara target baik secara bilateral maupun multilateral.

Tabel 1*

\section{Klasifikasi Diplomasi Militer India}

\begin{tabular}{|c|c|c|c|}
\hline Jenis & Tujuan & Peserta & Implikasi \\
\hline $\begin{array}{l}\text { Dialog politik, keamanan } \\
\text { dan strategi pertahanan }\end{array}$ & $\begin{array}{lr}\text { Menciptakan kesepahaman } \\
\text { di antara negara } \\
\text { partisipan,terkait } & \text { dengan } \\
\text { permasalahan } & \text { dan } \\
\text { kepentingan } & \text { bersama } \\
\text { diantara mereka } & \end{array}$ & $\begin{array}{l}\text { Bertingkat, mulai dari } \\
\text { kepala negara, sampai } \\
\text { pejabat kementerian, } \\
\text { jendral, dan kepala } \\
\text { batalyon. }\end{array}$ & $\begin{array}{l}\text { a. Penanggulangan } \\
\text { masalah } \\
\text { perbatasan antar } \\
\text { negara } \\
\text { b. Penanganan } \\
\text { terorisme }\end{array}$ \\
\hline $\begin{array}{l}\text { Penandatanganan } \mathrm{MoU} / \\
\text { Perjanjian Militer }\end{array}$ & $\begin{array}{l}\text { Peningkatan level di atas } \\
\text { menuju terbentuknya } \\
\text { perjanjian militer }\end{array}$ & $\begin{array}{l}\text { Antar Kepala Negara } \\
\text { kemudian implikasinya } \\
\text { diturunkan pada tingkat } \\
\text { kementerian }\end{array}$ & $\begin{array}{ll}\text { a. } & \text { MoU } \\
\text { b. } & \text { Military } \\
\text { Agreement } \\
\text { c. } \text { Treaties }\end{array}$ \\
\hline
\end{tabular}




\begin{tabular}{|c|c|c|c|}
\hline $\begin{array}{l}\text { Transparansi dalam } \\
\text { kebijakan militer nasional }\end{array}$ & $\begin{array}{l}\text { Keterlibatan suatu negara } \\
\text { anggota dalam masalah } \\
\text { kebijakan militer domestik } \\
\text { dari negara anggota lainnya }\end{array}$ & $\begin{array}{lr}\text { Peningkatan } & \text { partisipasi } \\
\text { kebijakan } & \text { militer } \\
\text { domestik antar negara di } \\
\text { tingkat } & \text { eksekutif, } \\
\text { legislatif } & \text { sampai } \\
\text { kelompok } & \text { kepentingan } \\
\text { dan swasta } & \end{array}$ & $\begin{array}{l}\text { Terbentuknya Tim } \\
\text { bersama dalam } \\
\text { latihan, intelegensi } \\
\text { sampai bantuan } \\
\text { teknologi bagi } \\
\text { pengembangan } \\
\text { kluster industri } \\
\text { militer }\end{array}$ \\
\hline $\begin{array}{l}\text { Bantuan penegakan hukum } \\
\text { atas Regim / Pemerintah } \\
\text { incumbent (petahana) di } \\
\text { suatu negara anggota }\end{array}$ & $\begin{array}{l}\text { Peningkatan intervensi } \\
\text { kebiakan pertahanan hingga } \\
\text { level operasional }\end{array}$ & Tentara nasional & $\begin{array}{l}\text { Fasilitasi pelatihan, } \\
\text { konsultasi, } \\
\text { peralatan tempur }\end{array}$ \\
\hline $\begin{array}{l}\text { Penempatan pejabat atau } \\
\text { tentara sbg personil militer } \\
\text { di suatu negara target / } \\
\text { antar negara anggota }\end{array}$ & $\begin{array}{l}\text { Terciptanya jaringan } \\
\text { komunikasi di antara } \\
\text { personil militer dari setiap } \\
\text { negara anggota }\end{array}$ & $\begin{array}{l}\text { Alumni latihan militer, } \\
\text { kursus yang telah } \\
\text { diselenggarakan subyek } \\
\text { perjanjian }\end{array}$ & $\begin{array}{l}\text { Pertukaran antar } \\
\text { pejabat dan personil } \\
\text { militer }\end{array}$ \\
\hline Diseminasi & $\begin{array}{l}\text { Penyamaan persepsi atas } \\
\text { suatu permasalahan } \\
\text { bersama dalam suatu forum }\end{array}$ & $\begin{array}{l}\text { Diikuti ketiga aktor } \\
\text { pembuat } \\
\text { militer }\end{array}$ & $\begin{array}{l}\text { Seminar, pameran } \\
\text { industri militer dan } \\
\text { pertahanan }\end{array}$ \\
\hline $\begin{array}{lr}\text { Partisipasi dalam operasi } \\
\text { perdamaian } & \text { dan } \\
\text { kemanusiaan } & \end{array}$ & $\begin{array}{l}\text { Peningkatan profesionalitas } \\
\text { dan integritas, harga diri } \\
\text { bangsa }\end{array}$ & $\begin{array}{l}\text { Tentara nasional, para } \\
\text { militer }\end{array}$ & $\begin{array}{l}\text { UN Peacekeeping, } \\
\text { UN Peace building } \\
\text { Humanitarian } \\
\text { disaster }\end{array}$ \\
\hline $\begin{array}{l}\text { Pengadaan kredit, bantuan } \\
\text { program maupun proyek } \\
\text { bagi industri khususnya } \\
\text { industri militer negara } \\
\text { target }\end{array}$ & $\begin{array}{l}\text { Terciptanya } \\
\text { kondusif bagi hubungan } \\
\text { ekonomi maupun militer } \\
\text { kedua negara }\end{array}$ & $\begin{array}{l}\text { Diikuti ketiga aktor } \\
\text { pembuat } \\
\text { militer }\end{array}$ & $\begin{array}{l}\text { a. Kredit } \\
\text { b. Bantuan } \\
\text { pengadaan } \\
\text { peralatan, } \\
\text { persenjataan } \\
\text { c. Kontrak } \\
\text { pembangunan } \\
\text { infrastruktur } \\
\text { telekomunikasi }\end{array}$ \\
\hline
\end{tabular}

*Sumber : Muthanna, KA. 2011. "Perspektif of Military Diplomacy". Journal of Defense Studies Vol

V No 1 (Januari) 
Antara diplomasi militer dengan deterrence (penangkal), saling terkait antara satu dengan lainnya. Yang terakhir menjadi fungsi utama dari konsep yang pertama. Fungsi ini menujuk pendapat Kamphausen ${ }^{10}$ mampu dijalankan cukup brilian oleh Tiongkok. Sebagai negara besar di Asia Selatan, maka India pun harus mampu menjalankannya. Ketika sampai pada peran penangkal, diplomasi militer sudah mulai berubah sifatnya dari pencegahan menjadi pemaksaan (coersive diplomacy) dan hanya senjata nuklir yang mampu menjalankannya. Penolakannya terhadap NPT (Non Proliferation Treaties), menyebabkan negara ini menghadapi persoalan lebih berat karena harus mengupayakan legitimasinya sebagai pengembang sekaligus negara bersenjata nuklir.

Diplomasi ekonominya dengan Kanada sejak tahun 1973 mampu mengatasi stagnasi hubungan India dengan Barat akibat penolakannya atas NPT. Program CANDU/Canada Deuterium Uranium, memfasilitasi alih teknologi energi nuklir, menghasilkan plutonium serta pengolahan thorium. Titik awal perkembangan militer India guna memperoleh legitimasi dari AS adalah perjanjian militernya dengan AS pada tahun $2005 .^{11}$

$$
\text { Kerjasama militer India-AS }
$$

merupakan salah satu bentuk kerjasama militer

\footnotetext{
${ }^{10}$ Kamphausen, Roy. Et all. 2010. The PLA at Home and Abroad: Assessing the Operational Capabilities of China's Military. Forbes Ave, Carlisle : All Strategic Studies Institute

11 "U.S. \& India Sign 10-Year Defense Pact" Jun 30,2005 in

http://www.defenseindustrydaily.com/us-indiasign-10year-defense-pact-0783/
}

multidimensional, antara dua negara dengan kekuatan militer asimetris. Penjanjian ini sarat dengan muatan ekonomi, politik maupun keamanan. India dalam melakukan diplomasi milter atas AS lebih didominasi oleh dengan motif ekonomi, untuk melakukan internalisasi atas industri militer domestik melalui kerjasama produksi sekaligus melakukan pembelian persenjataan modern. Sementara AS termotivasi oleh ambisinya untuk melakukan antisipasi akibat terganggunya keseimbangan kekuatan di Asia Selatan karena kekuatan militer Tiongkok terlalu dominan. ${ }^{12}$

Meskipun demikian sengketa kedua negara mengenai energi nuklir yang dikembangkan India justru menjadi kepentingan utama yang menyatukan motif mereka dalam mengadakan kerjasama. Pada tahun 2005 ditandatangani dua buah perjanjian militer guna mengadaptasikan kepentingan yang berbeda dari kedua negara. Yang pertama, pada tanggal 30 Juni 2005 ditandatangani naskah perjanjian yang berjudul New Framework for the US-India Defense Relationship" (NFDR). Dari muatannya cenderung untuk memenuhi kebutuhan India khususnya dalam perdagangan militer, kerjasama militer dan kerjasama produksi dengan melibatkan industri militer domestik India. $^{13}$

\footnotetext{
${ }^{12}$ Chesson,Roy David 2011."How China Could affect the Future of US Defense Corporations" tersedia dalam https://web.stanford.edu/group/sjeaa/journal111/Chi na3.pdf .

${ }^{13}$ Wadhwani Chair in U.S.-India Policy Studies in http://csis.org/program/us-india-security-anddefense-cooperation .
} 
Setengah bulan kemudian, tepatnya pada tanggal 18 Juli 2005 “United States-India Nuclear Cooperation Approval and Nonproliferation Enhancement Act". Dibandingkan dengan NFDR yang berdurasi sepuluh tahun, perjanjian kedua ini jangka waktunya tiga puluh tahun karena implikasinya menuntut waktu yang lebih lama. Sesuai perjanjian ini AS mengakui kedaulatan India sebagai negara yang memiliki senjata nuklir (Nuclear Weapon Statel NWS). Konsekuensinya AS harus menjamin keanggotaan India dalam kelompok negara pengekspor persenjataan modern seperti Wassenaar Arrangement (WA), Australia Group (AG), Nuclear Suppliers Group (NSG), dan Missile Technology Control Regime (MTCR). Sebaliknya India harus memberikan akses bagi IAEA (International Atomic Energy Association) untuk melakukan pengawasan atas 14 reaktor nuklirnya. Selain itu juga mendukung diplomasi militer yang dilakukan oleh AS guna menekan instalasi nuklir yang dilakukan oleh Iran, Korea Utara ${ }^{14}$

Secara umum sesuai dengan NFDR, dalam perdagangan militer, India mendapatkan dukungan dari AS guna mengikuti prosedur peningkatan kualitas dalam pengemasan ekspor persenjataan modern. Selain itu, India melakukan pembelian atas sejumlah persenjataan modern, termasuk diantaranya adalah rudal balistik Patriot melalui sistem kerjasama produksi sehingga memberikan

\footnotetext{
${ }^{14}$ Kronstadt, K Alan, et al 2005. "US -India Bilateral Agreement in "http://www.au.af.mil/au/awc/awcgate/crs/rl33072. pdf .
}

kesempatan bagi firma militer domestik untuk melakukan alih teknologi melalui sistem perakitan. Perjanjian yang ditandatangani ini sebenarnya jauh dari harapan India yang diajukan dalam perundingan sebelumnya. ${ }^{15}$

Dalam perdagangan militer India mengajukan pembelian rudal THAAD - rudal hasil kerjasama AS dengan Israel, namun AS hanya menyetujui rudal type Patriot $^{16}$, rudal anti tank Javelin pada awalnya juga juga ditolak oleh AS karena India dikhawatirkan akan mampu mempelajari sistem teknologinya $^{17}$, namun pada tahun 2013 akhirnya disetujui kerjasama produksi generasi baru dari Javelin. ${ }^{18}$ Pada tahun yang sama, AS akhirnya juga menyetujui pembelian pesawat tempur produksi Boeing, P8I. Pesawat ini dilengkapi radar berjangkauan sampai dasar lautan. India menjadi negara kedua setelah AS yang memiliki jenis ini. Dengan sistem kerjasama produksi maka proses akhir pembuatan pesawat ini dilakukan di India dengan melibatkan firma domestik sebagai sub kontraktor $^{19}$.

\footnotetext{
${ }^{15}$ Research Unit for Political Economy. 2006. "Why the United States Promotes India's Great - Power Ambitions". Monthly Review, Vol 57, Issue 10 (March) on http://monthlyreview.org/2006/03/01/why-theunited-states-promotes-indias-great-powerambitions/

${ }^{16}$ "U.S. \& India Sign 10-Year Defense Pact" Jun 30, 2005, $\log$ cit

17"'Indo -US Defense Technology Cooperation" by Sudesh Rani 28 Feb 2013 in http://maritimeindia.org/article/indo-us-defencetechnology-cooperation.

${ }^{18}$ "U.S., India Agree to Collaborate on Advanced Defense Technologies" Sept 30 2013. In http://www.nti.org/gsn/article/us-india-agreecollaborate-new-defense-technologies/.

19“"Indo-US Defense Technology Cooperation" by Sudesh Rani. Op cit
} 
Pola Kerjasama produksi antara AS dengan India hampir serupa dengan sistem leasing maupun offset yang pernah dilakukan oleh India dengan Rusia maupun beberapa negara Eropa. Perbedaannya adalah menyangkut jenis produk, tergolong jenis persenjataan modern milik kontraktor pertahanan AS, sehingga harus memperoleh persetujuan dari DOD berdasarkan NISPOM (National Industrial Security Program Operating Manual). Konsekuensinya jika India hendak membelinya dengan sistem kerjasama produksi, pemerintah AS harus mendapatkan persetujuan dari pihak Kongres AS. Karena proses produksi sepenuhnya masih dilakukan oleh suatu $M N C$ pertahanan, maka sistem ini secara langsung juga melibatkan jaringan $M N C$ pertahanan dalam proses internalisasi industri militer domestik. $^{20}$

$$
\text { Keberhasilannya sebagai negara }
$$

non NPT yang memperoleh status NWS/ Nuclear Weapons State, memperlancar diplomasi ekonominya dengan kelompok NSG (Nuclear Supplier Group) juga memberikan peluang langkah diplomasi militer lainnya, seperti latihan militer bersama serta tukar menukar informasi perkembangan teknologi persenjataan baik secara bilateral maupun multilateral. Semua program di atas

\footnotetext{
${ }^{20}$ NISPOM ditetapkan DoD, merupakan manual prosedur standar yang harus dipenuhi oleh seluruh kontraktor pemerintah AS , terkait dengan persoalan keamanan domestik sebagai bagian dari penyedia persenjataan DoD, maka kontraktor pertahanan seperti Boeing dalam menjalankan kerja sama internasionalnya, harus mentaati ketentuan di dalamnya. Uraian selngkapanya tersedia dalam http://www.dss.mil/documents/odaa/nispom20065220.pdf .
}

membangun kerangka diplomasi militer sebagai wahana penangkal bagi negara kawan maupun lawan sehingga segan ketika hendak menyerang atau menyatakan perang.

Fungsi kedua maupun ketiga merujuk pendapat Kamphausen setting agenda dan reassurance. Ketiga fungsi di atas saling melengkapi serta berhubungan antara satu dengan lainnya. Deterrence dan reassurance merupakan fungsi yang bersifat pasif karena bekerjanya dua fungsi ini tidak bisa dilihat secara nyata, melainkan Tampak dari berbagai sikap negara lain terhadap negara pelaku diplomasi. Berbeda dengan "setting agenda", sifatnya aktif dan tampak nyata proses dan langkahnya. India menjalankan fungsi kedua ini melalui keikutsertaannya secara aktif sebagai Pasukan Perdamaian PBB, dalam program peacekeeping maupun peacebuilding. Angkatan Bersenjata India sejak awal kemerdekaan sampai sekarang tercatat sebagai kontributor utamanya, bersama-sama dengan Pakistan dan Bangladesh. Partisipasinya berdampak ekonomis, maupun politis bagi kluster industri militer.

Keuntungan ekonomis dalam hal ini adalah membuka peluang bisnis non kombatan (sipil) maupun penjualan senjata artileri bagi DPSU /Defense Public Sector Undertaking, RUR maupun MSME. Peningkatan pasar sipil ini bagi kluster mengakselerasikan integrasi bisnis militer dengan sipil di segala aspek ekonomi domestik. India menjadi model bagi negara lainnya, bahwa persoalan pertahanan dan keamanan yang semakin komplek mengarahkan justifikasi bahwa bisnis militer 
pasti memberikan kontribusi bagi GNP dalam segala situasi, baik damai maupun perang.

Profesionalitasnya dalam sebuah misi perdamaian, membuat India disegani semua negara baik negara industri maupun berkembang. Secara politis, hal ini meyakinkan kontraktor pertahanan saat memutuskan melakukan investasinya di Bangalore juga Hyderabad sebagai kluster industri militer. Di samping Inggris, Perancis, dan Canada maka AS, Tiongkok, Taiwan bahkan Korea Selatan bersedia meningkatkan kerja sama ekonomi dan militernya. Dibandingkan dengan Pakistan, Korea Utara dan Sudan Selatan, sebagai negara penolak NPT, maka India menempati posisi strategis ketika melakukan perundingan dengan AS dan negara peratifikasi NPT lainnya.

Faktor agama Hindu dan kedekatannya dengan Rusia ketika merintis industri militer, semula menjadi kendala ketika India hendak menjalankan diplomasi militernya dengan Timur Tengah, Afrika dan Asia Tengah. Namun profesionalitasnya sebagai pasukan PBB secara tidak langsung mendekatkan komunikasinya dengan berbagai wilayah tetangganya ini. India bisa diterima oleh dua pihak bersengketa di Timur Tengah, misalnya Arab Saudi, Uni Emirat Arab di satu sisi dengan Israel di sisi lainnya.

\section{Asia Tenggara sebagai Pasar Industri Militer}

Industri militer memiliki sifat monopsoni, dalam arti hanya sedikit jumlah pembeli atas beragam produk barang dan jasa.
Penyebabnya adalah menurunnya daya beli serta meningkatnya berbagai kebutuhan lainnya sehingga faktor keamanan nasional tidak mendapatkan prioritas utama. Sifat ini berdampak pada rendahnya tingkat pengembalian (ROI) dari industri militer. Padahal karena tingginya tingkat pembiayaan, industri militer dituntut agar memiliki term of trade positif, nilai ekspor produksinya baik barang maupun jasa harus lebih besar daripada nilai impor.

Implikasinya, ketersediaan wilayah sebagai pasar tradisional atau potensi mutlak diperlukan. Pasar Tradisional merupakan segmen yang telah dikelola oleh suatu negara. Bagi India, Asia Selatan dan Asia Tengah (Negara CIS/ Common Independent State) merupakan pasar tradisional bagi kluster industri militernya. Sedangkan istilah kedua merujuk atas wilayah yang memiliki keunggulan mutlak maupun kompetitif berpotensi sebagai pasar industri militer, namun belum sepenuhnya diberdayakan karena keterbatasan modal. Tergolong di dalamnya adalah wilayah Asia Tenggara, Timur Tengah, Afrika dan Amerika Latin (Selatan).

Keberadaan Asia Selatan dan Asia Tengah (negara CIS) sebagai pasar tradisional bagi India bersifat taken for granted, dalam arti muncul karena India bagi kedua wilayah ini adalah lokasi terdekat (tetangga), memiliki cukup sumber daya alam maupun manusia yang mereka perlukan untuk memenuhi kebutuhan bagi angkatan bersenjata, industri militer dan sub sektor domestik mereka seperti kelistrikan, TI, pertambangan dan lain 
sebagainya. Hegemoni regional India atas kedua wilayah ini semakin memperkokoh kedudukan negara ini. Namun, pada beberapa wilayah yang tergolong pasar potensial seperti Asia Tenggara, Afrika, dan Timur Tengah membutuhkan penanganan yang lebih mendalam dari India melalui diplomasi ekonomi/ militer.

Data SIPRI tahun 1992 dan 2012 menunjukkan tingkat pembelanjaan militer wilayah Asia Tenggara cukup besar, menempati peringkat 12 besar (2012), bahkan melebihi Asia Selatan dan Asia Tengah. Namun mereka belum sepenuhnya berhasil dikembangkan sebagai pasar bagi industri militer India karena dominasi Rusia, Tiongkok, Korea Selatan, AS dan beberapa negara Eropa atas wilayah ini masih cukup besar. Ketika India berusaha memasuki kawasan ini, misalnya Myanmar, maka harus menghadapi banyak sekali hambatan eksternal dari semua negara di atas.

Peluang cukup luas terbuka bagi negara ini dalam bisnis non kombatan juga segmen jasa militer. India sudah berusaha meraih potensi pasar ini baik melalui kerja sama bilateral maupun multilateral, khususnya dengan ASEAN sebagai organisasi regional di kawasan ini. Tabel 2 dan 3, menunjukkan tingkat inventaris persenjataan tiga negara utama di area ini. Terlihat kepemilikan persenjataan modern mereka masih sangat minim, sedangkan daya beli mereka atas produksi militer dari Barat, Tiongkok dan Rusia terbatas. Apabila India berhasil menawarkan produksinya melaui konsep kerja sama ventura, peluang masih terbuka luas.

Tabel 2*

Perbandingan Tingkat Pembelanjaan Militer Asia Tenggara 1992 dan 2012

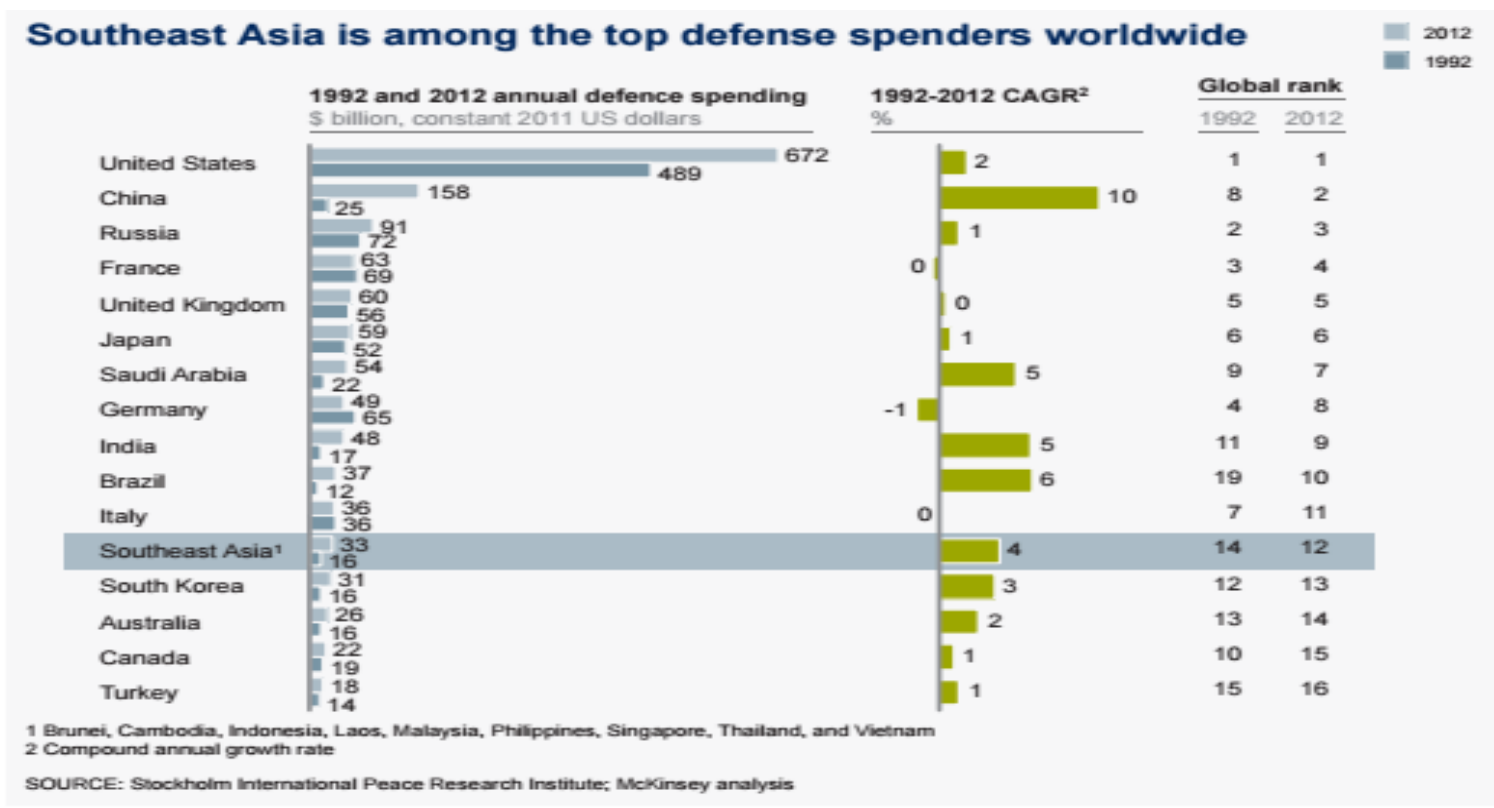


*Sumber: Dowdy, John et all.2014. "Southeat Asia : the next growth opportunity

inDefense".www.mckinsey.com/.../aerospace\%20and\%20defense/../sea\%20defen se data diakses pada tanggal 11 Juni 2015

Hubungan India dengan Asia

Tenggara secara historis sudah terbina selama berabad abad. Kaum Indian diaspora menjadi agen penyebaran berbagai agama dan budaya di wilayah ini. Paska dekolonisasi ( > 1945), kelompok ini, baik NRI (Non Resident India) maupun PIO (Person of Indian Origin) menjadi agen pembangunan serta pelaku diplomasi swasta baik melalui perusahaan, organisasi nirlaba maupun personal. Ikatan mereka dengan tanah aiir menjadi alat pemersatu kaum perantauan sehingga menyatukan kepentingan bisnis golongan dengan beragam prioritas pembangunan negeri ini.

Tabel 3*

Representasi Kepemilikan Persenjataan Modern Tiga Negara Utama Asia Tenggara

\section{Average age of fixed-wing fleet for select Southeast Asian countries}

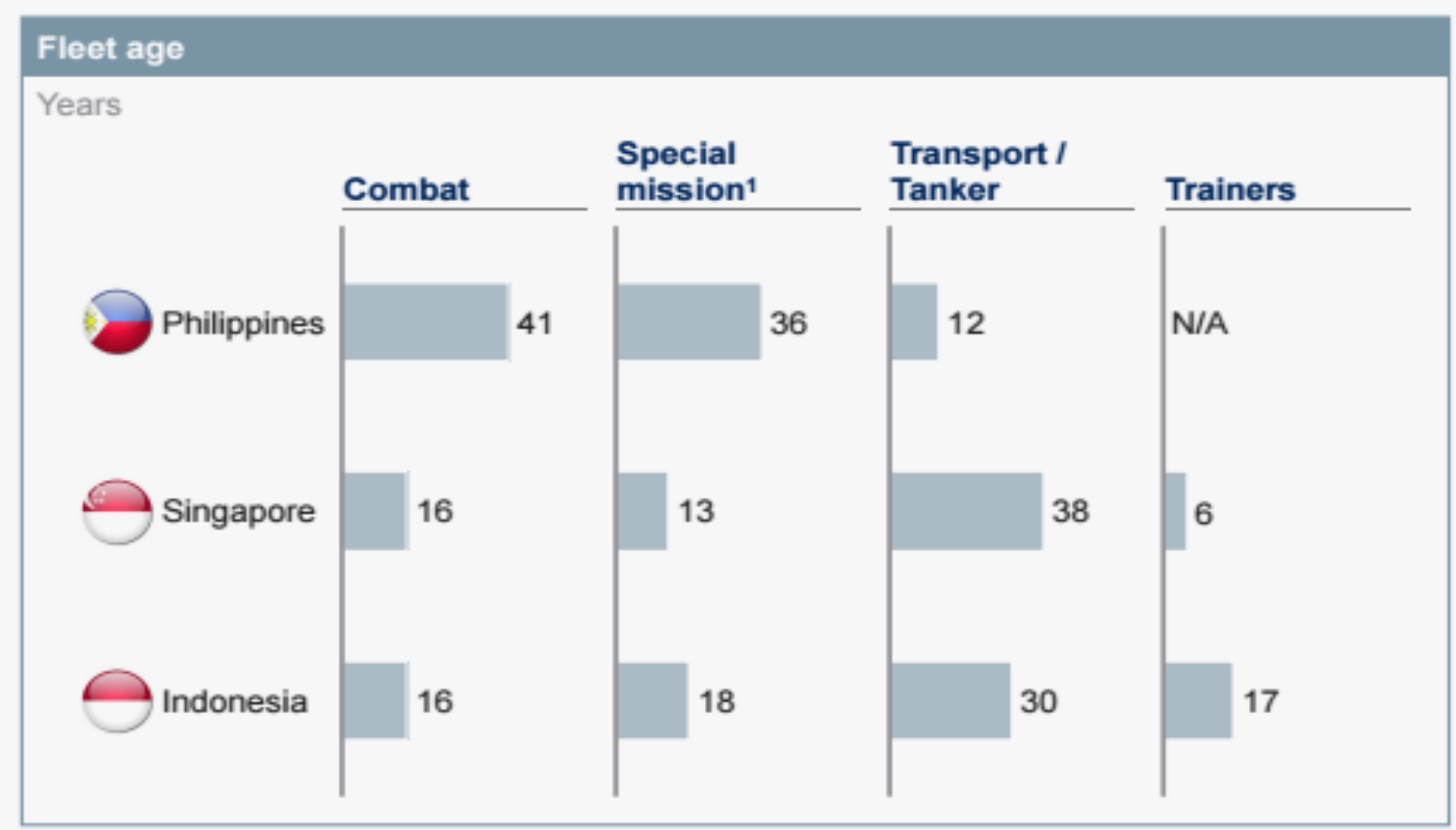

1 Includes maritime air patrol and airborne early warning

SOURCE: World Air Forces Directory; Aviation Week Intelligence Network, Press search, Mokinsey analysis

*Sumber : Dowdy, John et all.2014. "Southeat Asia : the next growth opportunity in Defense".www.mckinsey.com/.../aerospace\%20and\%20defense/.../sea\%20defen se data diakses pada tanggal 11 Juni 2015 pukul 16.10 


\section{Myanmar dan Industri Militer India}

Potensi pasar dari negara ini cukup besar karenaletak geografisnya bersebelahan langsung dengan India, menjadi tapal batas selatan dari negara bagian Mizoram, Manipur, Nagaland dan Arunachal Pradesh (India Barat Daya). Panjang daerah perbatasan ini lebih dari 1600 kilometer dan tergabung langsung dengan lokasi BCIM -EC (Bangladesh, China, India, Myanmar Economic Corridor), salah satu wilayah terkaya di dunia dengan keunggulan mutlak dalam mineral, gas bumi, hutan dan hasil pertanian. Potensi konflik negara tersebut, antara junta militer dengan kelompok pro demokrasi menambah nilai tawar bagi industri militer India.

Neraca perdagangan India Myanmar, selama bertahun tahun selalu negatif bagi India, sebagai penyeimbangnya beberapa perusahaan pengeboran minyak maupun RUR memiliki hak pengeboran minyak lepas pantai. Meskipun demikian sampai penulisan disertasi, India belum mampu secara optimal menjadikan negara tetangganya ini sebagai pangsa pasar industri militernya. Segmen produksi dan jasa yang telah ditempuh antara lain jasa pelatihan, konsultasi, dan bantuan teknologi.

Dalam usaha pemeliharaan potensi pasar, India harus bersaing dengan Tiongkok. Negara Tirai bambu ini merupakan rekanan ekonomi dan militer utama. Pertimbangan kompetisi inilah yang mendorong kebijakan India terhadap Myanmar bersifat elastis. Dukungannya atas Aung San Suu Kyi dan kelompok pro demokrasi tidak bisa bersifat tegas / frontal, karena kepentingan perusahaan domestiknya di negara tersebut menuntut sikap kompromi dengan Junta Militer.

Tabel 4*

Representasi Keterlibatan Firma Domestik India di Myanmar

\begin{tabular}{|c|c|c|c|}
\hline $\begin{array}{c}\text { Nama } \\
\text { Perusahaan }\end{array}$ & $\begin{array}{c}\text { Nilai Kontrak } \\
\text { (US \$) }\end{array}$ & Jenis Jasa & Lokasi \\
\hline Punj Lloyd & 475 juta & Oil and Gas Pipeline & \\
\hline \multirow[t]{2}{*}{$L \& T$} & 250 Juta & $\begin{array}{l}\text { Wellhead platform } \\
\text { pipeline }\end{array}$ & Zwatika \\
\hline & 112 juta & $\begin{array}{l}\text { Wellhead platform } \\
\text { pipeline }\end{array}$ & Yetagun \\
\hline Jubilant Energy & & PSC I Block & \\
\hline Nipha Export & 20 juta & $\begin{array}{l}\text { Multiple vegetable Oil } \\
\text { Processing Complex }\end{array}$ & \\
\hline Vihan Network & 5 juta & Mobile Telecom & \\
\hline Ltd & & & \\
\hline
\end{tabular}


Sumber : Mukhim, Patricia.2013.’'India -Myanmar Economic Partnership and the Development of India's North East.”.http://ris.org.in/images/RIS_images/pdf/IndiaMyanmar\%20Meeting\%204\%20feb\%202013\%20PPT/Patricia.pdfdata diakses pada tanggal 18 Juni 2015

Hubungan India dengan Myanmar telah mencapai seluruh tahapan obyek dalam diplomasi militer seperti tercantum dalam penjelasan sebelumnya. Alurnya secara alami terstruktur menuju penguatan jaringan industri militer kedua negara. Kecenderungan ini secara tidak langsung semakin mendekatkan India dengan Junta Militer Myanmar (SPDC/ State Peace and Development Council) dan menjauhkannya dari kelompok oposan pro demokrasi (Kubu NLD / National League for Democracy).

Titik balik perubahan hubungan India - Myanmar mulai terlihat sejak tahun 1998, ketika kepentingan penyaluran minyak bumi dari Myanmar bagi kepentingan industri domestik India semakin terancam. Tiga aspek perubahan dinamika kedua negara, menurut Rong Wang ${ }^{21}$ meliputi ekonomi dan perdagangan, bantuan pengembangan modal manusia dan bantuan teknis / infrastruktur. Bagi sub sektor industri militer ketiga aspek terimplikasikan sesuai Tabel di bawah ini.

\section{Tabel 5}

\section{Kluster Ekonomi dan Perdagangan}

Representasi RUR dan DPSU di Myanmar

\begin{tabular}{lll}
\hline \multicolumn{1}{c}{ Nama } & \multicolumn{1}{c}{ Jenis } & \multicolumn{1}{c}{ Uraian } \\
\hline Wipro Technologies Ltd & Sub Kontraktor Telenor Myanmar & Pengembangan jaringan \\
Tata Motor & $\begin{array}{l}\text { (cabang Telenor Norwegia) } \\
\text { Kerja sama ventura dengan Myanmar } \\
\text { Automobile \& Diesel Industries Ltd }\end{array}$ & $\begin{array}{l}\text { Pembangunan Pabrik truk } \\
\text { dan alat berat }\end{array}$ \\
& (SoE Myanmar) & \\
& Kerja sama ventura dengan AGI (Apex & Penjualan kendaraan sipil \\
& Greatest Industrial Co Ltd) & \\
Tata Consultancy Service dan & FDI & systems integration and \\
CMC & & asset-based solutions \\
Mahindra \& Mahindra & FDI & $\begin{array}{l}\text { Pendirian cabang guna } \\
\text { efektifitas penjualan produksi }\end{array}$ \\
Ashok Leyland & & $\begin{array}{l}\text { Pendirian cabang guna } \\
\text { efektifitas penjualan produksi }\end{array}$ \\
Kirloskar Ltd & FDI & Pendirian cabang guna
\end{tabular}

\footnotetext{
${ }^{21}$ Wang, Rong and Cuiping Zhu (ed). 2015. Annual Report on the Development of International Relations in the Indian Ocean Region (2014). New York : Springer.
} 


\begin{tabular}{lll}
\hline Tata Power Ltd & FDI & $\begin{array}{l}\text { efektifitas penjualan produksi } \\
\text { Pembangunan Pusat Listrik } \\
\text { Tenaga Batu Bara dan gas } \\
\text { Bumi (Geo thermal })\end{array}$ \\
Godrej & FDI & $\begin{array}{l}\text { Pendirian cabang guna } \\
\text { efektifitas penjualan produksi }\end{array}$ \\
Bharat Forge & FDI & Pendirian cabang guna \\
BEL (DPSU) & FDI & efektifitas penjualan produksi \\
HAL (DPSU ) & FDI & Sonar system on frigates \\
& & Upgrade fighter aircraft \\
GSL & Sale of Advanced light \\
hDI & helicopter \\
\hline
\end{tabular}

Tabel 6*

Kluster Bantuan Teknik dan Pengembangan Modal Manusia di Myanmar

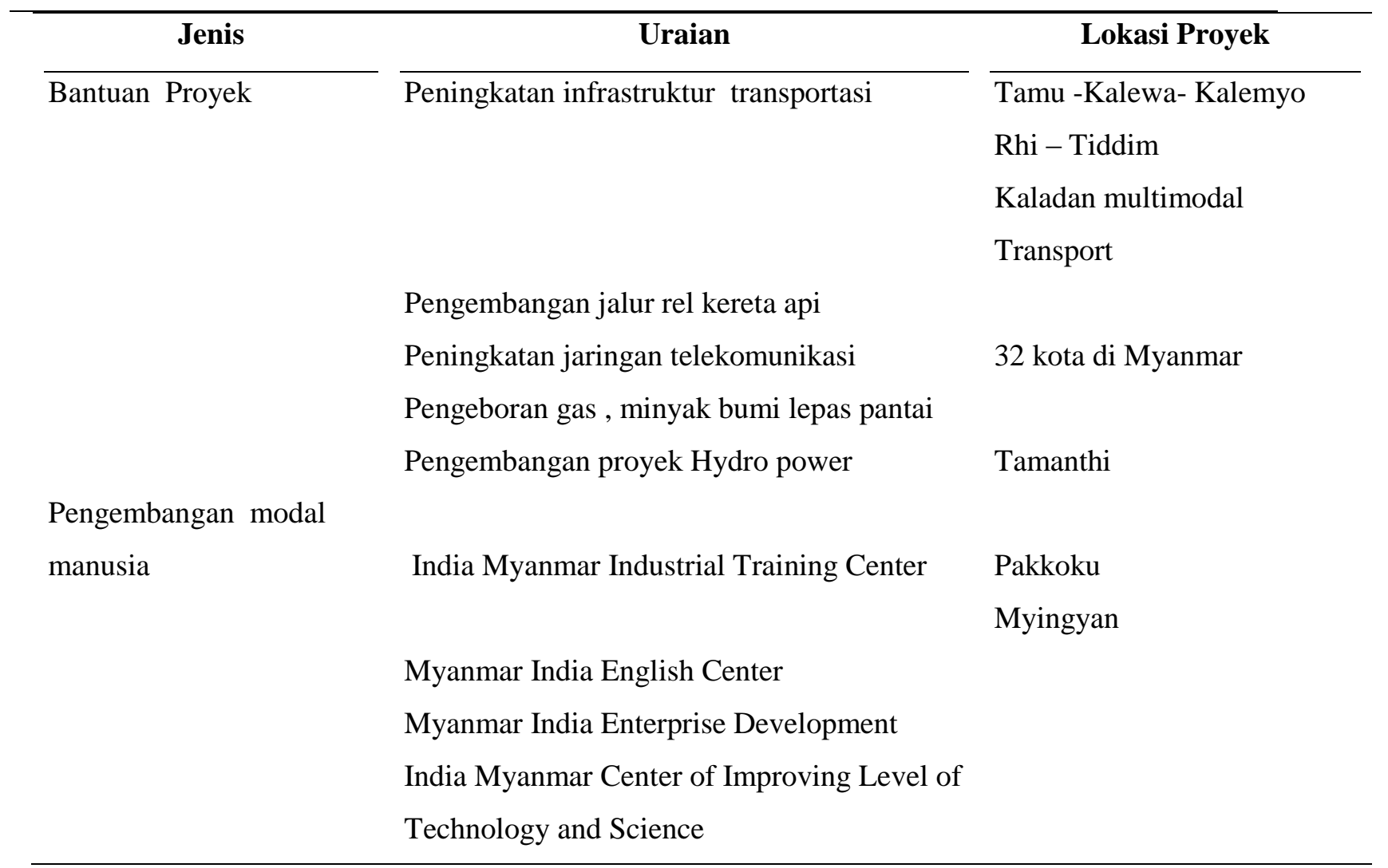

*Sumber : Wang, Rong and Cuiping Zhu (ed). 2015. Annual Report on the Development of International Relations in the Indian Ocean Region (2014). New York : Springer 


\section{Thailand dan Industri Militer India}

Seperti Myanmar, Thailand adalah rekanan tradisional / historis bagi India, ditinjau dari jumlah migran (Indian diaspora), persebaran agama Budha dan peningkatan jumlah NRI /PIO di wilayah negara ini. Perbedaannya Thailand tidak memiliki parameter intensitas konflik domestik serta bahan baku berlimpah seperti Myanmar.

Meskipun kerjasama ekonomi dan sosial budaya telah dijalankan melalui berbagai wahana, namun posisi neraca pembayaran India atas Thailand sampai tahun 2014 senantiasa negatif. Kompensasinya terhadap neraca modal kedua negara dijalankan melalui partisipasi swasta India dalam pembangunan domestik Thailand, baik dari RUR (Tata, Mahindra \& Mahindra), maupun MNC dan firma domestik India non RUR seperti Aditya Birla Group, Thai Baroda Industries, Usha Siam Steel Industries, Ranbaxy Laboratories, Lupin Laboratories, Indo - Rama Group, Infotech, Satyam Computer. ${ }^{22}$

Kendala peningkatan hubungan ekonomi kedua negara, khususnya bagi kepentingan industri militer adalah kesamaan kekayaan alam berakibat pada rendahnya nilai kelangkaan suatu item. Thailand lebih sering menjalankan transaksi pembelian persenjataan dengan AS, Uni Eropa dan Tiongkok karena potensi kelangkaan produksi perdagangan maupun counter trade di antara mereka lebih tinggi. Dampaknya, India harus melakukan impor mesin, baja sampai dengan kendaraan

\footnotetext{
${ }^{22}$ Barman, Arup. 2001. India - Thailand's Engagement in HRD Diplomacy A Case. SSRN Electronic Journal (July)
}

sebagai kompensasi sejumlah impor Thailand atas beragam produksi barang dan jasa India.

$$
\text { Guna membangkitkan potensi }
$$

perdagangan militer kedua negara perlu ditingkatkan diplomasi militer khususnya pelatihan, offset dan kerja sama ventura, terutama bagi bisnis non kombatan. Sejak 2002 inisiasi peningkatan kerja sama militer telah dijalankan, integral dengan beragam wahana yang telah ada. Di antara semua instrumen yang paling menonjol adalah potensi pengembangan modal manusia. Target jangka menengah adalah peningkatan investasi dan terjalinnya jaringan bilateral dalam pengadaan kebutuhan persenjataan Angkatan Bersenjata Thailand (Royal Thailand Army). 
Tabel 7

Wahana Kerja sama Ekonomi Sosial dan Budaya India - Thailand

\begin{tabular}{ll}
\hline Multilateral & \multicolumn{1}{c}{ BIMSTEC } \\
\hline & Trilateral transport linkage \\
& Asia Cooperation Dialogue \\
& ASEAN Regional Forum \\
& Mekong Gangga Cooperation \\
Bilateral & India - Thailand Free Trade Area \\
& India - Thailand Free Trade Area \\
& India - Thailand Double Taxation Agreement \\
\hline
\end{tabular}

Tabel 8

Kontribusi RUR /DPSU di Thailand

\begin{tabular}{lll}
\hline Nama & Jenis Kontribusi & Uraian \\
\hline TCS & Joint Venture P to P & \\
& (Firstech Solution) & $\begin{array}{l}\text { IT Outsourcing service } \\
\text { manufacturing, aviation } \\
\text { Tata - HAL }\end{array}$ \\
Mahindra Technology & Branch \\
Bharat Forge- Elbit & Branch & IT Outsourcing service \\
Systems (Israel) & provider of RTA & \\
& & ATMOS systems \\
Ashok Leyland & provider of RTA & vehicles for humanitarian \\
HCL Technologies & Branch & disaster \\
Larsen \& Toubro & provider of offshoring & IT Outsourcing service \\
infosys technologies & Provider & $\begin{array}{l}\text { Zwatika Development Project } \\
\text { IT Outsourcing service }\end{array}$ \\
Tata Motor & Provider & infrastructure project \\
\hline
\end{tabular}

\section{Singapura dan Industri Militer India}

Negara di tepi Selat Malaka ini memiliki posisi penting sebagai pasar potensial bagi industri militer India. Hubungan yang terjalin antara kedua negara lebih berdasarkan strategis pragmatis, bukan berdasarkan sosio historis. Posisi geopolitiknya menunjukkan dari kerangka "Look East Policy", India seharusnya mampu mengendalikan, memanfaatkan serta membangun jaringan 
dengannya guna kepentingan hegemoni Asia

Selatan,serta kelangsungan pembangunan domestik.

$\begin{array}{rcc}\text { Sebaliknya } & \text { Singapura juga } \\ \text { membutuhkan India } & \text { sebagai pasar bagi }\end{array}$ komoditas barang dan jasa andalannya. Dari sudut kluster industri militer, kedua negara masing masing memiliki kelebihan juga kekurangan. Melalui jaringan bilateral maupun multilateral kelemahan kluster industri militer bisa berkurang sementara potensi nilai lebihnya mampu ditingkatkan. Tabel 9 menunjukkan komparasi kelemahan dan keunggulan dari kluster industri militer kedua negara, setelah dipasangkan ke dalam suatu tabel matrik, terlihat keunggulan yang dimiliki kluster industri Singapura mampu mengurangi kelemahan kluster India begitu juga sebaliknya.

Tabel 9

Komparasi Kelemahan dan Keunggulan Kluster Industri Militer

Singapura - India

\begin{tabular}{|c|c|c|}
\hline Negara & Kelemahan & Keunggulan \\
\hline Singapura & $\begin{array}{l}\text { 1. Kurang sinergi antara inkubator, } \\
\text { katalisator dengan techno park sebagai } \\
\text { wahana kluster } \\
\text { 2. Minim konsumen / pelanggan } \\
\text { 3. Belum memiliki kebijakan pengembangan } \\
\text { kluster sebaik ketiga model } \\
\text { 4. Minim Sumber daya alam, khususnya } \\
\text { bahan baku bagi industri militer } \\
\text { 5. Belum mencapai teknologi nuclear sub } \\
\text { marine, maupun ICBM } \\
\text { 6. Wilayah negara sempit, sehingga } \\
\text { pengembangan kluster industri militer } \\
\text { mengalami stagnasi }\end{array}$ & $\begin{array}{l}\text { 1. Kompetensi jasa MRO bertaraf } \\
\text { global } \\
\text { 2. Dukungan manajemen } \\
\text { terstruktur dalam suatu techno } \\
\text { park, mampu mengintegrasikan } \\
\text { beragam unsur penunjang kluster } \\
\text { seperti pasar modal internasional, } \\
\text { bank, dan pasar modal. }\end{array}$ \\
\hline India & $\begin{array}{l}\text { Instrumen pemasaran kluster belum } \\
\text { bekerja optimal sehingga kompetensi } \\
\text { produksi persenjataan kurang dikenal } \\
\text { secara global dibandingkan dengan kedua }\end{array}$ & $\begin{array}{l}\text { 1. Terjadi sinergi antara inkubator, } \\
\text { katalisator dengan techno park } \\
\text { sebagai wahana kluster. } \\
\text { 2. Memiliki pasar tradisional maupun }\end{array}$ \\
\hline
\end{tabular}


model lainnya (Tiongkok)

Kluster industri militer Singapura mengacu pada model pertama (Tiongkok /Taiwan), bercirikan dominasi dari beragam GLC (Government Linked Company). Meskipun berlokasi di area sempit, pemerintah mampu melakukan manajemen TI sehingga Jurong Industrial Estate terkonsentrasi menjadi lima spesifikasi : a) Senjata artileri, mulai dari tank, senjata api dan small arm, berada di bawah koordinasi Singapore Technologies Engineering / STE; b) Perakitan dan MRO (Reparasi dan pemeliharaan) pesawat tempur dikordinir oleh Singapore Technologies Aerospace; c) Kapal dan senjata bagi angkatan laut dengan koordinator Singapore Technologies Marine; d) C4ISR dan elektronika berkoordinasi dengan Singapore Technologies Electronics dan dinamika (arm drone) dikendalikan Singapore Technologies Dynamic Pte.

Manajemen atas potensi pasar Singapura bagi industri militer India telah mencapai tahapan yang lebih tinggi apabila dibandingkan dengan pengelolaan terhadap Myanmar dan Thailand. Hampir seluruh RUR memliki kantor cabang di negara ini. Diantara RUR tersebut, yang paling menonjol adalah potensial

3. Kaya sumber daya alam , khususnya besi, baja aluminium sebagai bahan baku bagi industri militer

4. Telah mencapai teknologi nuclear sub marine dan ICBM
Tata dan Mahindra \& Mahindra Group. ${ }^{23}$

Temashek Holding Company sebagai

konsorsium milik pemerintah bahkan secara aktif menjadi broker bagi saham Ashok Leyland.

\footnotetext{
${ }^{23}$ Tech Mahindra, Mahindra Satyam, Mahindra Aerospace memiliki cabang di Singapura. Anand Mahindra dan Ratan Tata menjadi anggota International Advisory Council, dewan penasehat Economic Development Board Singapura
} 
Tabel 10

Kluster Kerja Sama India - Singapura

\begin{tabular}{|c|c|c|}
\hline Kluster & Segmen & Uraian \\
\hline India Singapore Special & & Capital, Connectivity, \\
\hline \multirow[t]{4}{*}{ Economic Zone } & Electronic Hardware & Capabilities, Comfort \\
\hline & $I T \& I T E S$ & \\
\hline & Manufacturing & \\
\hline & Logistic \& Warehousing & \\
\hline \multicolumn{3}{|l|}{ India Singapore military } \\
\hline \multirow[t]{5}{*}{ Exercises } & arm, navy, air (SIMBEX, SINDEX) & \\
\hline & coast patrol & \\
\hline & SAR Operation & \\
\hline & anti-piracy exercises & \\
\hline & Joint Working Group & \\
\hline \multicolumn{3}{|l|}{ Joint Science and Technology } \\
\hline \multirow[t]{2}{*}{ Committee } & advanced material \& Energy & \\
\hline & provider training for Singapore & \\
\hline \multirow[t]{2}{*}{ Military Training } & Airlines & \\
\hline & & Vistara (Tata sons - \\
\hline \multirow[t]{2}{*}{ Joint Venture / Production } & air lines & Singapore Air Lines \\
\hline & Techno park & Bangalore Techno Park \\
\hline \multicolumn{3}{|l|}{ Defence Procurement and } \\
\hline \multicolumn{3}{|l|}{ System Development Working } \\
\hline Group & Naval think tank, war ship & \\
\hline
\end{tabular}

\section{Kesimpulan}

Myanmar, Thailand dan Singapura menjadi tiga negara representasi di Asia Tenggara yang memiliki potensi tertinggi bagi peningkatan perdagangan militer India sekaligus kelangsungan inovasi kluster industri militer India. Masing-masing Negara memiliki spesifikasi khusus yang secara langsung menjadi keunggulan mutlak mereka terhadap India sebagai negara tetangga. Sementara bagi
India kebijakan terhadap mereka terangkum dalam konsep "Looking East Policy". Asia Tenggara dengan konsep ini seharusnya dijadikan sebagai rekanan utama, bahkan dalam jangka panjang ditargetkan diantara wilayah ini dengan India terbentuk hubungan patron klien atau setidaknya suatu kerja sama yang saling menguntungkan kedua belah pihak. 
Kemenangan mutlak Partai NDL

National League of Democracy ) atas partai pertahanan USDP (Union Solidarity and Development Party) dalam Pemilihan Umum Myanmar pada tanggal 8 November 2015 menempatkan India pada posisi yang lebih menguntungkan apabila dibandingkan dengan Tiongkok. Negara ini tinggal meningkatkan komunikasi serta dukungannya terhadap Aung San Suu Kyi, tanpa harus meninggalkan jaringan yang telah terbina dengan Junta Myanmar. Proses pengalihan kewenangan sejumlah aset domestik Myanmar tinggal menunggu hasil negosiasi antara pihak militer dengan NDL. Berbeda dengan Tiongkok yang semula menjadi rekanan utama Rezim Militer maupun USDP. Setelah suksesi nasional Myanmar, harus mengubah haluan kebijakan luar negerinya guna menjamin kelangsungan aset mereka disana.

Thailand memiliki kompetensi dalam kuantitas sumber daya manusia (NRI dan PIO). Jumlah ini diharapkan menjadi penjamin eksistensi investasi India di negara Gajah Putih ini. Dukungan ini sifatnya sangat solid karena berasal dari unsur nasionalitas India sebagai bangsa. Berbagai gejolak politik yang terjadi disana tidak mampu menghambat kemajuan investasi yang telah ditanamkan baik yang berasal dari swasta maupun pemerintah.

Keunggulan dalam manajemen techno park yang dimiliki Singapura sebanding dengan kelemahannya pada segmen sumber daya alam. Hal ini mampu diimbangi India dengan serangkaian kerja sama serta latihan militer. Interaksi kedua negara meluas sampai dengan kontribusi swasta India dalam penetapan kebijakan ekonomi negeri di ujung Selat Malaka ini. Dukungan kaum Indian Diaspora disana juga menjadi faktor penentu keberhasilan pemberdayaan negara ini sebagai pasar potensial industri militer India.

\section{Daftar Referensi}

\section{Buku}

Bitzinger, Richard A. 2009. The Modern Defense Industry : Political, Economy, Technological Issues. California : ABC-CLIO

Hoyt, Timothy d. 2006, Military industry and regional defense policy: India, Iraq, and Israel, London: Routledge.

Nye, Joseph Samuel. Jr. 2004. Soft Power : the Means to Success in World Politics. New York : Public Affairs 2010.Cyber Power. Belfer Center for Science \& International Affairs .May. '2011. The Future of Power. New York. Public Affairs

Rana, Kishan S \& Bipul Chatterjee. 2011. Economic Diplomacy : India's Experience. Rajasthan : CUTS International

Wang, Rong and Cuiping Zhu (ed). 2015. Annual Report on the Development of International Relations in the Indian Ocean Region (2014). New York : Springer.

Kamphausen,Roy. Et all. 2010. The PLA at Home and Abroad : Assessing the Operational Capabilities of China's Military. Forbes Ave, Carlisle : All Strategic Studies Institute

\section{Jurnal}

Neuman, Stephanie G. 1994. "Arm Transfers, Military Assistance, and Defense Industries : Socio economic Burden or Opportunity ?". Annal of the American Academy of Political and Social Science Vol 535 : The Arm Trade : Problem and Prospect in the Post Cold War World (Sept) 
Ross, Andrew L. Peter Dombrowski. 2008.'The Revolution in Military Affairs, Transformation and the Defence Industry". Security Challenges, Vol. 4, No. 4 (Summer)

Barman, Arup. 2001. India - Thailand's Engagement in HRD Diplomacy A Case. SSRN Electronic Journal (July)

Muthanna, KA. 2011. "Perspektif of Military Diplomacy". Journal of Defense Studies Vol V No 1 (January)

\section{Artikel}

Biegon, Rubrick. 2013. "The Banality of Smart Power : Reconstituting US Hegemony after Bush".International Paper that was submitted for University of Kent POLIR Post Grad Conference 17 May.

\section{Internet}

Dowdy, John et all.2014. "Southeat Asia : the next growth opportunity in Defense".www.mckinsey.com/.../aer ospace $\% 20$ and $\% 20$ defense/.../sea $\% 2$ Odefense

"Indo -US Defense Technology Cooperation" by Sudesh Rani 28 Feb 2013 in http://maritimeindia.org/article/indous-defence-technology-cooperation
Kronstadt, K Alan, et al 2005. "US -India Bilateral Agreement in "http://www.au.af.mil/au/awc/awcgat e/crs/rl33072.pdf

Mukhim, Patricia.2013.'India -Myanmar Economic Partnership and the Development of India's North East.".http://ris.org.in/images/RIS_im ages/pdf/India-

Myanmar\%20Meeting\%204\%20feb $\% 202013 \% 20 \mathrm{PPT} / \mathrm{Patricia} . \mathrm{pdf}$

Research Unit for Political Economy. 2006. "Why the United States Promotes India's Great - Power Ambitions". Monthly Review, Vol 57, Issue 10 (March) on http://monthlyreview.org/2006/03/01/ why-the-united-states-promotesindias-great-power-ambitions/

"U.S., India Agree to Collaborate on Advanced Defense Technologies" Sept 302013. In http://www.nti.org/gsn/article/usindia-agree-collaborate-new-defensetechnologies/

"U.S. \& India Sign 10-Year Defense Pact" Jun 30, 2005 in http://www.defenseindustrydaily.com /us-india-sign-10year-defense-pact0783/

Wadhwani Chair in U.S.-India Policy Studies in http://csis.org/program/us-indiasecurity-and-defense-cooperation 